\title{
ABSTRACT \\ LEGAL PROTECTION FOR PARKING SERVICE USERS KAPUAS \\ REGIONAL REGULATION NUMBER 2 OF 2010 CONCERNING RETRIBUTION OF PARKING SERVICES AT THE EDGE OF THE PUBLIC ROAD \\ Raihani \\ Kuala Kapuas College of Law
}

The purpose of this study is to find the concept of the substance of the rules that do not harm the community from minor mistakes that are made repeatedly every day, without a good and clear solution, as well as the duties and roles of the Regional Government and related institutions in making it safe and comfortable for parking service users. in Kapuas Regency.

The research carried out was normative legal research, namely research on the principles of law and the prevailing positive legal doctrine. performed analytically inductively. The process starts from premises in the form of known positive legal norms and ends with the discovery of legal principles and then doctrines. In this case, examining the legal norms in positive law using the statutory approach (Statute approach) which still needs to be rearranged, especially regarding the juridical consequences of the application of Kapuas District Regulation No. 2 of 2010 concerning Parking Service Retribution on the Side of Public Roads. In addition, this study uses a conceptual approach to examine existing problems by describing them as a comparison to the concepts contained in

articles of legislation.

Research Findings This is a business actor in the parking service business, both government-owned and private, who tries to shift the burden of responsibility to consumers for loss or damage to vehicles or consumer valuables in the parking lot managed by them. Of course this is contrary to Law No. 8 of 1999 concerning Consumer Protection.

Keywords: Legal Protection, Parking Service Users, Retribution 


\section{ABSTRAK \\ PERLINDUNGAN HUKUM BAGI PENGUNA JASA PARKIR \\ PERATURAN DAERAH KABUPATEN KAPUAS NOMOR 2 TAHUN 2010 TENTANG RETRIBUSI PELAYANAN PARKIR DI TEPI JALAN UMUM

\author{
Raihani
}

Sekolah Tinggi Ilmu Hukum Kuala Kapuas

Tujuan penelitian ini menemukan konsep substansi aturan yang tidak merugikan masyarakat dari kesalahan kecil yang dilakukan berulang-ulang kali setiap hari, tanpa ada penyelesaian yang baik dan jelas, serta tugas dan peranan Pemerintah Daerah maupun lembaga terkait dala hal membuat aman dan nyaman untuk penguna jasa parkir yang ada di Kabupaten Kapuas.

Penelitian yang dilaksanakan adalah penelitian Hukum Normatif (normative legal research), yaitu penelitian terhadap Asas-asas Hukum dan doktrin hukum positif yang berlaku. yang dilakukan secara analitis induktif. Prosesnya dimulai dari premis-premis yang berupa norma hukum positif yang diketahui dan berakhir pada penemuan asas-asas hukum dan selanjutnya doktrin-doktrin. Dalam hal ini menelaah terhadap norma hukum dalam hukum positif dengan menggunakan pendekatan Perundang-undangan (Statute approach) yang mana masih perlu dilakukan penataan ulang khususnya mengenai konsekuensi yuridis dari penerapan Peraturan Daerah Kabupaten Kapuas No. 2 Tahun 2010 tentang Retribusi Pelayanan Parkir Di Tepi Jalan Umum. Selain itu penelitian ini menggunakan pendekatan Konsep (Conseptual approach) untuk menelaah permasalahan yang ada dengan cara menguraikan sebagai perbandingan pada konsep yang terdapat dalam pasal perundang-undangan dan perjanjian/kontrak .

Temuan Penelitian ini adalah adanya pelaku usaha pada bisnis jasa perparkiran, baik milik pemerintah maupun milik swasta yang berusaha mengalihkan beban tanggung jawabnya kepada konsumen atas kehilangan atau kerusakan kendaraan atau barang berharga konsumen di lahan parkir yang dikelola olehnya. Tentu hal demikian bertentangan dengan Undang-Undang No. 8 Tahun 1999 tentang Perlindungan Konsumen.

Kata Kunci : Perlindungan Hukum, Pengguna Jasa Parkir, Retribusi 


\section{PENDAHULUAN}

\section{A. Latar Belakang}

Pesatnya pembangunan dan perkembangan perekonomian nasional telah menghasilkan variasi produk barang dan/atau jasa yang dapat dikonsumsi. Kemajuan di bidang ilmu pengetahuan, teknologi telekomunikasi dan informatika juga turut mendukung perluasan ruang gerak transaksi barang dan/atau jasa hingga melintasi batasbatas wilayah suatu negara. Kondisi demikian pada satu pihak sangat bermanfaat bagi kepentingan konsumen karena kebutuhannya akan barang dan/atau jasa yang diinginkan dapat terpenuhi serta semakin terbuka lebar kebebasan untuk memilih jenis kualitas barang dan/atau jasa sesuai dengan kemampuannya.

Perkembangan dalam teknologi dan pola kegiatan ekonomi membuat masyarakat di dunia tidak hanya saling bersentuhan, saling membutuhkan dan saling menentukan nasib satu sama lain, tetapi juga saling bersaing. Realita ini menempatkan negara untuk benar-benar dan bersungguh-sungguh mengikuti dan mengembangkan hukum bisnis secara global, terutama dalam pelaksanaannya atau penegakan hukumnya.

Di dalam masyarakat orang saling mengadakan hubungan yang jumlah dan sifatnya tak terhingga banyaknya. Orang-orang itu mempunyai kepentingan masingmasing dan masyarakat memungkinkan kepentingan-kepentingan itu bertemu dalam suatu kontak yang erat. Usaha melindungi dan memperkembangkan kepentingankepentingan dapat dicapai karena sebelumnya telah diadakan peraturan-peraturan yang dapat menjadi ukuran bagi tingkah laku orang.

Kehadiran hukum dalam masyarakat di antaranya adalah untuk mengintegrasikan dan mengkoordinasikan kepentingan-kepentingan yang bisa bertubrukan antara satu sama lain oleh hukum diintegrasikan sedemikian rupa sehingga tubrukan-tubrukan itu bisa ditekan sekecil-kecilnya.

Dalam bisnis usaha baik usaha perdagangan barang maupun usaha perdagangan jasa, pelaku usaha memegang peranan yang sangat penting dalam transaksi yang terjadi di dalam usaha perdagangan. Berdasarkan Undang-Undang No. 8 Tahun 1999 tentang Pelindungan Konsumen atau disingkat dengan UUPK, Pasal 1 angka 3, pelaku usaha adalah:

"pelaku usaha adalah setiap orang perseorangan atau badan usaha, baik yang berbentuk badan hukum maupun bukan badan hukum yang didirikan dan berkedudukan atau melakukan kegiatan dalam wilayah hukum negara republik indonesia, baik sendiri maupun bersama-sama melalui perjanjian menyelenggarakan kegiatan usaha dalam berbagai bidang ekonomi" .

Dalam dunia bisnis usaha ada juga yang berperan sebagai konsumen. Tanpa konsumen, pelaku usaha tidak dapat menghasilkan keuntungan. Berdasarkan Pasal 1 angka 2 UUPK, konsumen adalah:

"konsumen adalah setiap orang pemakai barang dan/atau jasa yang tersedia dalam masyarakat, baik bagi kepentingan diri sendiri, keluarga, orang lain, maupun makhluk hidup lain dan tidak untuk diperdagangkan" . 
Pelaku usaha dan konsumen sangat erat kaitannya satu sama lain karena masing-masing mempunyai kewajiban dan hak serta tanggung jawab yang harus terpenuhi. Apabila salah satu pihak atau kedua belah pihak kewajiban dan hak serta tanggung jawab darinya tidak terpenuhi maka akan menimbulkan kerugian salah satu pihak atau kedua pihak tersebut. Salah satu bidang bisnis usaha dalam jasa yaitu bisnis jasa perparkiran. Dalam jasa parkir tentu tidak lepas dengan kendaraan.

Semua orang yang mempunyai kendaraan pasti akan membutuhkan lahan atau tempat parkir untuk memarkir kendaraannya dalam waktu sementara. Dengan hal tersebut, banyak pelaku usaha yang membuka bisnis jasa perparkiran Tentu hal ini merupakan suatu bisnis yang cukup menguntungkan, mengingat kendaraan yang demikian banyak, sudah pasti membutuhkan lahan parkir. Tetapi tentu tak mudah membuka bisnis jasa parkir mengingat ada beberapa hal yang harus dipenuhi, diantaranya kewajiban dan tanggung jawab dari bisnis jasa parkir itu sendiri.

Hukum perlindungan konsumen dewasa ini mendapat cukup perhatian karena menyangkut aturan-aturan guna mensejahterahkan masyarakat, bukan saja masyarakat selaku konsumen saja yang mendapat perlindungan konsumen, namun pelaku usaha juga mempunyai hak yang sama untuk mendapatkan perlindungan konsumen, masing-masing ada hak dan kewajiban. Pemerintah berperan mengatur, mengawasi dan mengontrol, sehingga tercipta sistem yang kondusif saling berkaitan satu dengan yang lain dengan demikian tujuan mensejahterahkan masyarakat secara luas akan tercapai. Selain itu perlu juga menjadi perhatian terhadap konsumen dalam melaksanakan kewajibannya sebagai konsumen, terkadang pelaku usaha sudah membuat ketentuan atau aturan guna keselamatan, kenyamanan dan keamanan, tapi terkadang juga konsumen tidak melaksanakan ketentuan atau aturan yang telah ditetapkan oleh pelaku usaha penyedia jasa parkir tersebut.

Adanya kelalaian konsumen dalam melaksanakan kewajibannya, maka gugurlah hak konsumen untuk meminta ganti rugi yang dideritanya, karena kerugian yang ditimbulkan disebabkan oleh kelalaiannya sendiri. Namun, dalam bisnis jasa perparkiran, kelalaian konsumen tidak menghapuskan beban tanggung jawab dari pelaku usaha bisnis jasa perparkiran. Konsumen masih berhak menuntut ganti kerugian kepada pelaku usaha jasa parkir, tapi apabila kelalaian semata-mata murni dari konsumen itu sendiri, maka pelaku usaha dibebaskan dari tanggung jawabnya, hal demikian dikarenakan hubungan antara pelaku usaha jasa parkir dan konsumen pengguna jasa parkir termasuk perjanjian penitipan barang.

Berdasarkan Pasal 1694 BW:

"penitipan adalah terjadi, apabila seseorang menerima sesuatu barang dari seorang lain, dengan syarat bahwa ia akan menyimpannya dan mengembalikannya dalam ujud asalnya."

Undang-undang perlindungan konsumen mengatur tentang tanggung jawab pelaku usaha atau jasa usaha sebagaimana disebutkan dalam pasal 19 yang memberikan suautu pelindungan terhadap konsumen. Dalam pasal 19 UUPK berisi tentang pelaku usaha bertanggung jawab memberikan ganti rugi atas kerusakan, pencemaran dan/atau kerugian konsumen akibat mengkonsumsi barang dan atau jasa yang dihasilkan atau diperdagangkan. Undang-undang perlindungan konsumen tidak dimaksudkan untuk 
mematikan usaha para pelaku usaha, tapi justru sebaliknya yaitu mendorong terciptanya iklim berusaha yang sehat, serta lahirnya perusahaan yang tangguh melalui penyediaan barang dan/jasa yang berkualitas.

\section{B. Permasalahan}

Akibat hukum bagi pengguna jasa parkir di tepi jalan umum atas kajian terhadap Perda Kab. Kapuas No.2 Tahun 2010 tentang Retribusi Pelayanan Parkir Di Tepi Jalan Umum dan Undang-Undang No. 8 Tahun 1999 tentang Perlindungan Konsumen.

\section{Metode}

Penelitian yang dilaksanakan adalah penelitian Hukum Normatif (normative legal research), yaitu penelitian terhadap Asas-asas Hukum dan doktrin hukum positif yang berlaku. yang dilakukan secara analitis induktif. Prosesnya dimulai dari premis-premis yang berupa norma hukum positif yang diketahui dan berakhir pada penemuan asas-asas hukum dan selanjutnya doktrin-doktrin. Berdasarkan hal tersebut di atas maka tipe penelitian ini adalah tipe Penelitian hukum murni, yakni penelitian dengan dasar pandangan bahwa hukum adalah norma-norma positif dalam sistem perundang-undangan hukum nasional. Dengan berorientasi pada pemahaman yang positivistik dengan metode doktrional.

Penulis dalam hal ini menelaah terhadap norma hukum dalam hukum positif dengan menggunakan pendekatan Perundang-undangan (Statute approach) yang mana masih perlu dilakukan penataan ulang khususnya mengenai konsekuensi yuridis dari penerapan Peraturan Daerah Kabupaten Kapuas No. 2 Tahun 2010 tentang Retribusi Pelayanan Parkir Di Tepi Jalan Umum dan Undang-Undang Nomor 8 Tahun 1999 Tentang Perlindungan Konsumen. Selain itu penelitian ini menggunakan pendekatan Konsep (Conseptual approach) untuk menelaah permasalahan yang ada dengan cara menguraikan sebagai perbandingan pada konsep yang terdapat dalam pasal perundangundangan dan perjanjian/kontrak

\section{HASIL DAN PEMBAHASAN}

\section{a. Konsep Hukum Perlindungan Konsumen}

Konsumen Perlindungan konsumen adalah segala upaya yang menjamin adanya kepastian hukum untuk memberi perlindungan kepada konsumen. Rumusan pengertian perlindungan konsumen yang terdapat dalam Pasal 1 Angka 1 Undang-Undang Nomor 8 Tahun 1999 tentang Perlindungan Konsumen (UUPK) tersebut cukup memadai. Kalimat yang menyatakan "segala upaya yang menjamin adanya kepastian hukum”, diharapkan sebagai benteng untuk meniadakan tindakan sewenang-wenang yang merugikan konsumen hanya untuk kepentingan pelaku usaha. Meskipun Undang-Undang ini disebut sebagai Undang-Undang Perlindungan Konsumen namun bukan berarti kepentingan pelaku usaha tidak ikut menjadi perhatian karena keberadaan perekonomian nasional banyak di tentukan oleh pelaku usaha.Kesewenang-wenangan akan mengakibatkan ketidakpastian hukum. Oleh karena itu, agar segala upaya memberikan jaminan akan kepastian hukum, ukurannya secara kualitatif ditentukan dalam UUPK dan UndangUndang lainnya yang juga dimaksudkan masih berlaku untuk memberikan perlindungan 
terhadap konsumen, baik dalam bidang Hukum Privat (Perdata) maupun hukum publik (Hukum Pidana dan Hukum Adminisrasi Negara) Keterlibatan berbagai disiplin ilmu sebagaimana dikemukakan diatas, memperjelas kedudukan Hukum Perlindungan Konsumen berada dalam kajian Hukum Ekonomi.

Ada korelasi yang bersifat timbal-balik antara kepastian hukum dan perlindungan konsumen yang menjadikan inti dari perlindungan hukum adalah kepastian hukum. Jika kepastian hukum dapat tercapai maka perlindungan hukum juga terpenuhi, dengan demikian berdasarkan ketentuan UUPK ada dua persyaratan utama dalam perlindungan konsumen yaitu:

1. Adanya jaminan hukum (law guarantee), peraturan yang melindungi hak konsumen terhadap perilaku dari pelaku usaha, peraturan tersebut menjamin para subyek hukum.

2. Adanya kepastian hukum (law Certainly), perlindungan hukum pada tingkat normatif dan empiris.

Undang-Undang sebagai sarana yang maksimal untuk mencapai ksejahteraan untuk itu perlu dipenuhi syarat-syarat seperti keterbukaan dan hak kepada warga masyarakat untuk partisipasi publik.

Asas keseimbangan menjadi salah satu asas dalam UUPK ditetapkan dalam Pasal 2 yang dalam penjelasan dinyatakan, asas keseimbangan dimaksudkan untuk memberikan keseimbangan antara konsumen, pelaku usaha dan pemerintah dalam arti materiil maupun spiritual. Asas-asas dalam UUPK dapat dikualifikasikan sebagai asas umum karena memuat rumusan bersifat umum yang juga dapat diterapkan dalam peraturan perundangundangan lain. Berikut lima asas perlindungan konsumen menurut UUPK, yaitu:

Asas manfaat dimaksudkan untuk mengamanatkan bahwa segala upaya dalam menyelenggarakan perlindungan konsumen harus memberikan manfaat sebesar-besarnya bagi kepentingan konsumen dan pelaku usaha secara keseluruhan.

Asas keadilan dimaksudkan agar partisipasi seluruh rakyat dapat diwujudkan secara maksimal dan memberikan kesempatan kepada konsumen dan pelaku usaha untuk memperoleh haknya dan melaksanakan kewajibannya secara adil.

Asas keseimbangan dimaksudkan untuk memberikan keseimbangan antara kepentingan konsumen, pelaku usaha, dan pemerintah dalam arti materiil dan spiritual.

Asas keamanan dan keselamatan konsumen dimaksudkan untuk memberikan jaminan atas keamanan dan keselamatan kepada konsumen dalam penggunaan, pemakaian, dan pemanfaatan barang dan/jasa yang dikonsumsi dan digunakan.

Asas kepastian hukum dimaksudkan agar pelaku usaha maupun konsumen menaati hukum dan memperoleh keadilan dalam menyelenggarakan perlindungan konsumen, serta negara menjamin kepastian hukum.

Radbruch menyebutkan keadilan, kemanfaatan, dan kepastian hukum sebagai tiga ide dasar hukum, yang berarti dapat dipersamakan dengan asas hukum. Di antara ketiga asas tersebut yang menjadi sorotan utama adalah masalah keadilan dimana Friedman menyebutkan bahwa: 
In terms of law, justice will be judged as how law treats people and now it distributes its benefits and cost, dan dalam hubungan ini Friedman juga menyatakan bahwa every function of law, general or specific, is allocative.

Sebagai asas hukum, dengan sendirinya menempatkan asas ini yang menjadi rujukan pertama baik dalam peraturan perundang-undangan maupun dalam berbagai aktivitas yang berhubungan dengan gerakan perlindungan konsumen oleh semua pihak yang terlibat di dalamnya. Keadilan, kemanfaatan, dan kepastian hukum juga oleh banyak jurist (ahli hukum) disebutkan sebagai tujuan hukum. Tujuan hukum untuk mencapai keadilan, kemanfaatan, dan kepastian hukum semuanya tergantung dari kondisi yang ada atau dihadapi di dalam setiap kasus.

\section{b. Tujuan Hukum Perlindungan Konsumen}

Achmad Ali mengatakan masing-masing Undang-Undang memiliki tujuan khusus. Hal itu juga tampak dari pengaturan Pasal 3 UUPK, yang mengatur tujuan khusus perlindungan konsumen, sekaligus membedakan dengan tujuan sebagaimana dikemukakan berkenaan dengan Pasal 2 di atas. Tujuan Perlindungan Konsumen menurut UUPK, yaitu:

a) Meningkatkan kesadaran, kemampuan, dan kemandirian konsumen untuk melindungi diri.

b) Mengangkat harkat dan martabat konsumen dengan cara menghindarkannya dari ekses negatif pemakaian dan/atau jasa.

c) Meningkatkan pemberdayaan konsumen dalam memilih, menentukan, dan menuntut hak-haknya sebagai konsumen.

d) Menciptakan sistem perlindungan konsumen yang mengandung unsur kepastian hukum dan keterbukaan informasi serta akses untuk mendapatkan informasi.

e) Menumbuhkan kesadaran pelaku usaha mengenai pentingnya perlindungan konsumen sehingga tumbuh sikap yang jujur dan bertanggung jawab dalam berusaha.

f) Meningkatkan kualitas barang dan/jasa yang menjamin kelangsungan usaha produksi barang dan/jasa, kesehatan, kenyamanan, keamanan, dan keselamatan konsumen. Pasal 3 UUPK ini, merupakan isi pembangunan nasional sebagaimana disebutkan dalam Pasal 2 sebelumnya, karena tujuan perlindungan konsumen yang ada itu merupakan sasaran akhir yang harus dicapai dalam pelaksanaan pembangunan di bidang hukum perlindungan konsumen.

\section{c. Konsumen}

Pasal 3 Undang-Undang Nomor 8 Tahun 1999 Tentang Perlindungan Konsumen Az. Nasution menegaskan beberapa batasan tentang konsumen, yakni Konsumen adalah setiap orang yang mendapatkan barang atau jasa yang digunakan untuk tujuan tertentu; Konsumen antara adalah setiap orang yang mendapatkan barang dan/atau jasa untuk digunakan dengan tujuan membuat barang dan/atau jasa lain untuk diperdagangkan (tujuan komersial), bagi konsumen antara barang dan/atau jasa itu adalah barang atau jasa 
kapitan yang berupa bahan baku, bahan penolong atau komponen dari produk lain yang akan diproduksinya (produsen). Konsumen antara ini mendapatkan barang dan/atau jasa di pasar industri atau pasar produsen. Konsumen akhir adalah setiap orang yang mendapat dan menggunakan barang dan/atau jasa untuk tujuan memenuhi kebutuhan hidupnya pribadi, keluarga dan/atau rumah tangga dan tidak untuk diperdagangkan kembali (non komersial).

Sementara itu pengertian konsumen menurut Pasal 1 ayat 2 UUPK, yaitu: Konsumen adalah setiap orang yang memakai barang dan/atau jasa yang tersedia dalam masyarakat, baik bagi kepentingan diri sendiri, keluarga, orang lain, maupun makhluk hidup lain dan tidak untuk diperdagangkan. Berdasarkan pengertian di atas subjek yang disebutkan sebagai konsumen berarti setiap orang yang berstatus sebagai pemakai barang dan/atau jasa. Akan tetapi yang dapat dikualifikasikan sebagai konsumen sesungguhnya tidak hanya terbatas pada subjek hukum yang disebut "orang" melainkan masih ada subjek lain yang juga dapat disebut sebagai konsumen yaitu "badan hukum” .

Perlindungan Konsumen didasarkan pada pemikiran bahwa pembangunan perekonomian nasional pada era globalisasi harus dapat mendukung tumbuhnya dunia usaha sehingga mampu menghasilkan beraneka barang dan/atau jasa yang memiliki kandungan teknologi yang dapat meningkatkan kesejahteraan masyarakat banyak dan sekaligus mendapatkan kepastian atas barang dan/atau jasa yang diperoleh dari perdagangan tanpa mengakibatkan kerugian konsumen. Semakin terbukanya pasar nasional sebagai akibat dari proses globalisasi ekonomi harus tetap menjamin peningkatan kesejahteraan masyarakat serta kepastian atas mutu, jumlah, dan keamanan barang dan/atau jasa yang diperolehnya di pasar, sehingga untuk meningkatkan harkat dan martabat konsumen perlu meningkatkan kesadaran, pengetahuan, kepedulian, kemampuan, dan kemandirian konsumen untuk melindungi dirinya serta menumbuhkembangkan sikap perilaku usaha yang bertanggungjawab. Sebagai pemakai barang dan/atau jasa, konsumen memiliki sejumlah hak dan kewajiban. Pengetahuan tentang hak-hak konsumen sangat penting agar konsumen dapat mengetahui secara kritis dan mandiri apabila mendapat tindakan yang tidak adil terhadap dirinya. Konsumen kemudian bisa bertindak lebih jauh untuk memperjuangkan hak-haknya. Dengan kata lain, ia tidak hanya tinggal diam saja ketika menyadari bahwa hak-haknya telah dilanggar oleh pelaku usaha.

Pasal 4 Undang-Undang Perlindungan Konsumen mengatur bahwa Hak konsumen adalah: a. Hak atas kenyamanan, keamanan, dan keselamatan dalam mengkonsumsi barang dan/atau jasa; b. Hak untuk memilih barang dan/atau jasa serta mendapatkan barang dan/atau jasa tersebut sesuai dengan nilai tukar dan kondisi serta jaminan yang dijanjikan; c. Hak atas informasi yang benar, jelas, dan jujur mengenai kondisi dan jaminan barang dan/atau jasa; d. Hak untuk didengar pendapat dan keluhannya atas barang dan/atau jasa yang digunakan; e. Hak untuk mendapatkan advokasi, perlindungan, dan upaya penyelesaian sengketa perlindungan konsumen secara patut; f. Hak untuk mendapat pembinaan dan pendidikan konsumen; g. Hak untuk diperlakukan atau dilayani secara benar dan jujur serta tidak diskriminatif; h. Hak untuk mendapatkan kompensasi, ganti rugi dan/atau penggantian, apabila barang dan/atau jasa yang diterima tidak sesuai dengan perjanjian atau tidak sebagaimana mestinya; i. Hakhak yang diatur dalam ketentuan peraturan perundang-undangan lainnya pada dasarnya terdapat tiga macam hak berdasarkan sumber pemenuhannya, yakni: 
a. Hak manusia karena kodratnya, yakni hak yang kita peroleh begitu kita lahir, seperti hak untuk hidup dan hak untuk bernafas. Hak ini tidak boleh diganggu gugat oleh negara, bahkan negara wajib untuk menjamim pemenuhan hak tersebut.

b. Hak yang lahir dari hukum, yakni hak yang diberikan oleh negara kepada warga negaranya. Hak ini juga disebut sebagai hak hukum. Contohnya hak untuk memberikan suara dalam pemilihan umum.

c. Hak yang lahir dari hubunngan kontraktual. Hak ini didasarkan pada perjanjian /-kontrak antara orang yang satu dengan orang yang lain. Contohnya pada peristiwa jual beli, hak pembeli adalah untuk menerima barang, dan hak penjual adalah untuk menerima pembayaran.

Pasal 5 Undang-Undang Perlindungan Konsumen mengatur bahwa Kewajiban Konsumen adalah Membaca atau mengikuti petunjuk informasi dan prosedur pemakaian atau pemanfaatan barang dan/jasa, demi keamanan dan keselamatan; Beritikad baik dalam melakukan transaksi pembelian barang dan/atau jasa; Membayar sesuai dengan nilai tukar yang disepakati; Mengikuti upaya penyelesaian hukum sengketa perlindungan konsumen secara patut.

Kewajiban-kewajiban yang dibebankan kepada konsumen diharapkan dapat menjadi pengendali hak-hak yang dimiliki oleh konsumen, sehingga dalam menggunakan haknya, konsumen tidak bertindak dengan sewenang-wenang. Hak yang dimiliki oleh konsumen baru dapat dipenuhi apabila kewajibannya telah dikerjakan terlebih dahulu.

\section{d. Pelaku Usaha}

Pelaku usaha merupakan istilah yuridis dari produsen. Istilah produsen berasal dari bahasa Belanda yakni producent dan dari bahasa Inggris producer yang artinya adalah penghasil. Pengertian pelaku usaha telah diatur menurut pasal 1 angka 3 UUPK, yaitu menyebutkan bahwa:

"Pelaku usaha adalah setiap orang perseorangan atau badan usaha, baik yang berbentuk badan hukum maupun bukan badan hukum yang didirikan dan berkedudukan atau melakukan kegiatan dalam wilayah hukum negara Republik Indonesia, baik sendiri maupun bersama-sama melalui perjanjian menyelenggarakan kegiatan usaha dalam berbagai bidang ekonomi.”

Pada pasal 1 angka 5 Undang-Undang No. 13 Tahun 2003 tentang Ketenagakerjaan juga memberikan pengertian pelaku usaha, yaitu pengusaha adalah Orang perorangan, persekutuan, atau badan hukum yang menjalankan suatu perusahaan milik sendiri; Orang perorangan, persekutuan, atau badan hukum yang menjalankan suatu perusahaan yang bukan miliknya; Orang perorangan, persekutuan, atau badan hukum yang berada di Indonesia mewakili perusahaan sebagaimana dimaksud angka (1) dan (2) yang berkedudukan di luar wilayah Indonesia. 2827 Lihat Pasal 1 Angka 3 UndangUndang Nomor 8 Tahun 1999 Tentang Perlindungan Konsumen LN No. 42 Tahun 1999. TLN No. 382128 Lihat Pasal 1 Angka 5 Undang-Undang No.8 Tahun 1999 Tentang Perlindungan Konsumen. LN No. 42 Tahun 1999. TLN No. 3821221. 
Hak Pelaku Usaha Pelaku usaha melakukan usahanya dengan tujuan memperoleh keuntungan dari produk yang ia tawarkan kepada konsumen, baik itu berupa barang dan/atau jasa. Kemudian dalam melakukan hubungan dengan konsumen, pelaku usaha mempunyai hak-hak dan kewajiban yang juga telah diatur didalam UUPK. Mengenai hak-hak pelaku usaha diatur dalam pasal 6 UUPK, yang menyebutkan bahwa hak pelaku usaha adalah: i) Hak untuk menerima pembayaran yang sesuai dengan kesepakatan mengenai kondisi dan nilai tukar barang dan/atau jasa yang diperdagangkan; ii) Hak untuk mendapat perlindungan hukum dari konsumen yang beritikad tidak baik; iii) Hak untuk melakukan pembelaan diri sepatutnya di dalam penyelesaian hukum sengketa konsumen; iv) Hak untuk rehabilitasi nama baik apabila terbukti secara hukum bahwa kerugian konsumen tidak diakibatkan oleh barang dan/atau jasa yang diperdagangkan; v) Hak-hak yang diatur dalam peraturan perundangan-undangan lainnya.

Mengenai kewajiban pelaku usaha terdapat dalam Pasal 7 UUPK, yang menyebutkan bahwa kewajiban pelaku usaha adalah: i) Beritikad baik dalam melakukan usahanya; ii) Memberikan informasi yang benar, jelas dan jujur mengenai kondisi dan jaminan barang dan/atau jasa serta memberi penjelasan penggunaan, perbaikan dan pemeliharaan; iii) Memperlakukan atau melayani konsumen secara benar dan jujur serta tidak diskriminatif; iv) Menjamin mutu barang dan/atau jasa yang diproduksi dan/atau diperdagangkan berdasarkan ketentuan standar mutu barang dan/atau jasa yang berlaku; v) Memberi kesempatan kepada konsumen untuk menguji, dan/atau mencoba barang dan/atau jasa tertentu serta memberi jaminan dan/atau garansi atas barang yang dibuat dan/atau diperdagangkan; vi) Memberi kompensasi, ganti rugi dan/atau penggantian atas kerugian akibat penggunaan, pemakaian dan pemanfaatan barang dan/atau jasa yang diperdagangkan; vii) Memberi kompensasi, ganti rugi dan atau penggantian apabila barang dan/atau jasa yang diterima atau dimanfaatkan tidak sesuai dengan perjanjian.

\section{e. Tanggung Jawab Hukum}

\section{Prinsip dan Teori Tanggung Jawab}

Fault)

1) Prinsip Tanggung Jawab Berdasarkan Unsur Kesalahan (Liability Based on

Prinsip tanggung jawab berdasarkan unsur kesalahan (liability based on fault) ini adalah prinsip yang berlaku dalam hukum pidana dan perdata. Dalam Kitab Undang-undang Hukum Perdata, khususnya pasal 1365, 1366, dan 1367, prinsip ini dipegang secara teguh. Prinsip ini menyatakan seseorang baru dapat dimintakan pertanggungjawaban secara hukum jika ada unsur kesalahan yang dilakukannya. Pasal 1365 KUHPerdata, yang lazim dikenal sebagai pasal tentang perbuatan melanggar hukum, mengharuskan terpenuhi empat unsur pokok, yaitu adanya perbuatan, adanya unsur kesalahan, adanya kerugian yang diderita, dan adanya hubungan kausalitas antara kesalahan dengan kerugian. Mengenai beban pembuktiannya, asas ini mengikuti ketentuan Pasal 163 Herzien Inlandsch Reglement (HIR) atau Pasal 283 Rechtsreglement voor de Buitengewesten (RBG) dan Pasal 1865 Kitab Undang-Undang Hukum Perdata, dalam ketiga pasal tersebut diatur bahwa barangsiapa yang mengaku mempunyai suatu hak, harus membuktikan adanya hak atau peristiwa itu (actorie incumbit probatio). Ketentuan di atas 
juga sejalan dengan teori umum dalam hukum acara, yakni asas audi et alterm partem atau asas kedudukan sama antara semua pihak yang berperkara. Pada hal ini hakim harus memberi para pihak beban yang seimbang dan patut, sehingga masing-masing memiliki kesempatan yang sama untuk memenangkan perkara tersebut.

2) Prinsip Praduga untuk Selalu Bertanggung Jawab (Presumption of Liability)

Prinsip praduga untuk selalu bertanggung jawab (presumption of liability principle) menyatakan, tergugat dianggap selalu bertanggung jawab, sampai pelaku usaha dapat membuktikan ada pada si tergugat. Saat ini, beban pembuktian terbalik (omkering van bewijslast) masih dapat diterima dengan prinsip praduga untuk selalu bertanggung jawab. Dasar pemikiran dari teori pembalikan beban pembuktian adalah seseorang yang dianggap bersalah, sampai yang bersangkutan dapat membuktikan sebaliknya. Hal ini tentu bertentangan dengan asas hukum praduga tidak bersalah (presumption of innocence) yang lazim dikenal dalam hukum. Namun, jika diterapkan dalam kasus konsumen akan tampak, asas demikian cukup relevan. Jika digunakan teori ini, maka yang berkewajiban untuk membuktikan kesalahan itu ada dipihak pelaku usaha yang digugat. Tergugat ini yang harus menghadirkan bukti-bukti, dirinya tidak bersalah. Tentu saja konsumen tidak lalu berarti dapat sekehendak hati mengajukan gugatan. Posisi konsumen sebagai penggugat selalu terbuka untuk digugat balik oleh pelaku usaha, jika ia gagal menunjukkan kesalahan tergugat.

3) Prinsip Praduga untuk Tidak Selalu Bertanggung Jawab

Prinsip praduga untuk tidak selalu bertanggung jawab adalah kebalikan dari prinsip praduga untuk selalu bertanggung jawab. Prinsip praduga untuk tidak selalu bertanggung jawab (presumption of non-liability principle) hanya dikenal dalam lingkup transaksi konsumen yang sangat terbatas, dan pembatasan demikian biasanya secara dapat dibenarkan. Contoh dari penerapan prinsip ini adalah pada hukum pengangkutan. Kehilangan atau kerusakan pada bagasi kabin/bagasi tangan, yang biasanya dibawa dan diawasi oleh si penumpang (konsumen) adalah tanggung jawab dari penumpang. Dalam hal ini, pengangkut (pelaku usaha) tidak dapat diminta pertanggungjawabannya.

4) Prinsip Tanggung Jawab Mutlak

Prinsip tanggung jawab mutlak (strict liability) sering diidentikkan dengan prinsip tanggung jawab absolut (absolute liability). Kendati demikian ada pula para ahli yang membedakan kedua terminologi di atas. Ada pendapat yang mengatakan, strict liability adalah prinsip tanggung jawab yang menetapkan kesalahan tidak sebagai faktor yang menentukan. Namun, ada pengecualianpengecualian yang memungkinkan dibebaskan dari tanggung jawab, misalnya dalam keadaan force majeure. Sebaliknya absolute liability adalah prinsip tanggung jawab tanpa kesalahan dan tidak ada pengecualiannya. 
5) Prinsip Tanggung Jawab dengan Pembatasan

Prinsip tanggung jawab dengan pembatasan (limitation of liability principle) sangat disenangi oleh pelaku usaha untuk dicantumkan sebagai klausula eksonerasi dalam perjanjian standar yang dibuatnya. Dalam perjanjian cuci cetak film, misalnya ditentukan bila film yang ingin dicuci/dicetak itu hilang atau rusak (termasuk kesalahan petugas), maka si konsumen hanya dibatasi ganti kerugiannya sebesar sepuluh kali harga satu rol film baru. Secara umum, prinsip tanggung jawab ini sangat merugikan konsumen bila ditetapkan secara sepihak oleh pelaku usaha. Undang-Undang Perlindungan Konsumen mengatur bahwa tidak dibolehkan secara sepihak menentukan klausula yang merugikan konsumen, termasuk membatasi maksimal tanggung jawabnya.

Jika ada pembatasan, mutlak harus berdasarkan pada peraturan perundang-undangan yang jelas. Menurut Abdulkadir Muhammad teori tanggung jawab dalam perbuatan melanggar hukum (tort liability) dibagi menjadi beberapa teori, yaitu : Tanggung jawab akibat perbuatan melanggar hukum yang dilakukan dengan sengaja (intertional tort liability), tergugat harus sudah melakukan perbuatan sedemikian rupa sehingga merugikan penggugat atau mengetahui bahwa apa yang dilakukan tergugat akan mengakibatkan kerugian.

Tanggung jawab akibat perbuatan melanggar hukum yang dilakukan karena kelalaian (negligence tort lilability), didasarkan pada konsep kesalahan (concept of fault) yang berkaitan dengan moral dan hukum yang sudah bercampur baur (interminglend).

Tanggung jawab mutlak akibat perbuatan melanggar hukum tanpa mempersoalkan kesalahan (stirck liability), didasarkan pada perbuatannya baik secara sengaja maupun tidak sengaja, artinya meskipun bukan kesalahannya tetap bertanggung jawab atas kerugian yang timbul akibat perbuatannya.

\section{f. Tinjauan Tentang Klausula Baku}

1. Klausula Baku Pengertian klausula Baku atau standard contract menurut UUPK yaitu: Setiap aturan atau ketentuan dan syarat-syarat yang telah dipersiapkan dan ditetapkan terlebih dahulu secara sepihak oleh pelaku usaha yang dituangkan dalam suatu dokumen dan/atau perjanjian yang mengikat dan wajib dipenuhi oleh konsumen. Pengertian klausula baku menurut E. H. Hondius yaitu konsep janji-janji yang tertulis yang disusun tanpa membicarakan isinya, serta pada umumnya dituangkan dalam perjanjianperjanjian yang tidak terbatas jumlahnya, namun sifatnya tertentu. Menurut Drion, setidaknya ada tiga aspek negatif dari klausula baku yang terjadi dalam praktik bisnis dan keuangan. Tiga aspek itu yaitu:

a) Penyusunan sepihak

pihak-pihak yang menyusun kontrak kurang memperhatikan kepentingan pihak lainnya.

b) Tidak diketahuinya isi syarat 
pihak-pihak yang ikut serta umumnya tidak maklum terhadap isi kontrak dan tidak mengetahui huruf-huruf kecil di sebelah belakang yang sering terdapat.

c) Kedudukan terjepit

pihak-pihak yang ikut serta berada dalam posisi terjepit. Adanya aspek-aspek negatif dari klausula baku yang tentunya juga membuktikan bahwa ada ketidakadilan yang dilakukan para pelaku usaha terhadap konsumen, jadi sudah sewajarnya bagi UUPK membuat larangan mengenai klausula baku ini.

Pembahasan mengenai ketentuan pencantuman klausula baku terdapat dalam Pasal 18 UUPK : a. Menyatakan pengalihan tanggung jawab pelaku usaha;b.Menyatakan bahwa pelaku usaha berhak menolak menyerahkan kembali barang yang dibeli konsumen; c.Menyatakan bahwa pelaku usaha berhak menolak penyerahan kembali barang yang dibeli konsumen;d.Menyatakan pemberian kuasa dari konsumen kepada pelaku usaha baik secara langsung maupun tidak langsung untuk melakukan segala tindakan. sepihak yang berkaitan dengan barang yang dibeli oleh konsumen secara angsuran; e. Mengatur perihal pembuktian atas hilangnya kegunaan barang atau pemanfaatan jasa yang dibeli oleh konsumen; $f$. Memberi hak kepada pelaku usaha untuk mengurangi manfaat jasa atau mengurangi harta kekayaan konsumen yang menjadi objek jual beli jasa; g. Menyatakan tunduknya konsumen kepada peraturan yang berupa aturan baru, tambahan, lanjutan dan/atau pengubahan lanjutan yang dibuat sepihak oleh pelaku usaha dalam masa konsumen memanfaatkan jasa yang dibelinya; h. Menyatakan bahwa konsumen memberi kuasa kepada pelaku usaha untuk membebankan hak tanggungan, hak gadai, atau hak jaminan terhadap barang yang dibeli oleh konsumen secara angsuran.

Ciri Klausula Baku Secara sederhana, perjanjian baku mempunyai ciri-ciri sebagai berikut: i) Perjanjian dimuat secara sepihak oleh produsen yang posisinya relatif lebih kuat dari konsumen; ii) Konsumen sama sekali tidak dilibatkan dalam menentukan isi perjanjian; iii) Dibuat dalam bentuk tertulis dan massal

Konsumen terpaksa menerima isi perjanjian didorong oleh kebutuhan. Namun Hondius juga mengatakan pendapat penulis-penulis Belgia dan Perancis tentang ciri-ciri Standaard voorwarrden atau adhesie contract, yaitu: i) Mengenal suatu tawaran umum, kadang-kadang ditambahkan syarat waktu tertentu; ii) Syarat-syarat disusun oleh salah satu pihak; iii) Syarat-syarat itu disusun terlebih dahulu; iv) Dengan cara abstrak dan bersifat umum (suatu hubungan hukum yang konkret yang diabstrakkan); v) Suatu rangkuman janji-janji beberapa pengarang, malah mengatakan semua hal yang sekecilkecilnya pun telah diatur; vi) Pihak yang menawarkan berada dalam posisi monopoli setidak-tidaknya ia berada dalam situasi ekonomi yang lebih unggul; vii) Tentang penawaran tidak dapat dibantahkan.

Bentuk Klausula baku dan Jenis Perjanjian dengan Klausula baku. Jika dicermati berdasarkan pengertian UUPK dapat disimpulkan bahwa klausula baku terdiri atas dua bentuk, yaitu Dalam Bentuk Perjanjian Konsep dalam suatu perjanjian telah dipersiapkan terlebih dahulu oleh pelaku usaha. Perjanjian ini biasanya memuat aturan-aturan umum dalam suatu perjanjian, persyaratan-persyaratan khusus mengenai pelaksanaan perjanjian, serta hal-hal mengenai berakhirnya perjanjian. Contohnya: kontrak baku, syarat-syarat tentang resiko tertentu, dan lainnya. 
Dalam Bentuk Persyaratan Perjanjian dalam bentuk ini dapat pula dalam bentuk bentuk lain, yaitu syaratsyarat khusus yang termuat dalam berbagai kuitansi, tanda penerimaan atau tanda penjualan, atau dalam secarik kertas tertentu yang termuat di dalam kemasan atau pada wadah produk yang bersangkutan.

Menurut Mariam Darus Badrulzaman, kontrak baku dapat digolongkan dalam jenis yaitu Kontrak baku sepihak adalah kontrak yang ditentukan oleh pihak yang kuat kedudukannya di dalam kontrak itu. Pihak yang kuat di sini ialah pihak kreditur yang lazimnya mempunyai posisi ekonomi kuat dibandingkan pihak debitur.

Kontrak baku timbal balik adalah kontrak baku yang isinya ditentukan oleh kedua pihak misalnya kontrak baku yang pihak-pihaknya terdiri dari pihak kreditur dan pihak lainnya yaitu debitur.kedua pihak lazimnya terikat dalam organisasi kontrak baku yang ditetapkan pemerintah ialah kontrak baku yang isinya ditentukan oleh pemerintah terhadap perbuatan-perbuatan hukum tertentu, misalnya kontrak-kontrak yang mempunyai objek hak-hak atas tanah.

Kebebasan berkontrak berlatar belakang pada paham individualime yang secara embrional lahir dalam zaman Yunani, dteruskan oleh Epicuristen dan berkembang pesat dalam zaman Renaissance melalui ajaran-ajaran Hugo de Groot, Thomas Hobbes, John Locke, dan Rousseau. Puncak perkembangannya tercapai dalam periode setelah Revolusi Prancis.

Definisi perjanjian dalam Pasal 1313 KUH Perdata yaitu: "perjanjian adalah suatu perbuatan dengan mana satu orang atau lebih mengikatkan dirinya terhadap satu orang atau lebih mengikakan dirinya terhadap satu orang atau lebih”. Di Indonesia hukum perjanjian menganut beberapa asas hukum salah satunya yaitu asas kebebasan berkontrak (freedom of contract) yang di atur dalam Pasal 1320 KUHPerdata. Dengan adanya asas ini para pihak yang membuat dan mengadakan perjanjian diperbolehkan untuk menyusun dan membuat kesepakatan atau perjanjian yang melahirkan kewajiban apa saja, selama dan sepanjang prestasi yang wajib dilakukan tersebut bukanlah sesuatu yang terlarang.

Menurut Abdulkadir, isi perjanjian terdiri dari syarat-syarat yang tegas (expers term), syarat yang diam-diam (implied term) dan klausula penyampingan. Syarat-syarat yang tegas adalah syarat-syarat yang secara khusus disebutkan dan disetujui oleh pihakpihak pada waktu membuat perjanjian. Syarat-syarat yang diam-diam adalah syarat yang tidak ditentukan secara tegas mengenai suatu hal dalamPerjanjian. Klausula penyampingan adalah untuk membatasi tanggung jawab salah satu pihak. Namun, harus dipahami bahwa maksud dari Pasal 1320 KUHPerdata yang merupakan hukum peninggalan kolonial Belanda adalah asas kebebasan berkontrak dapat diterapkan apabila kedudukan para pihak seimbang. Apabila kedudukan para pihak tidak seimbang, penerapan asas kebebasan berkontrak akan membawa kecenderungan terjadinya eksploitasi dari pihak yang kuat (produsen/pelaku usaha) kepada pihak yang lemah (konsumen). Di Belanda, tempat KUHPerdata dibuat, untuk mencegah terjadinya eksploitasi pihak yang kuat kepada pihak yang lemah dalam perjanjian baku, telah dilakukan re-interpretasi dari asas kebebasan berkontrak yaitu :

a) Asas kebebasan berkontrak bukan lagi dipahami dalam pengertian mutlak seperti yang terjadi di Indonesia tetapi dalam arti relative. Artinya asas 
kebebasan berkontreak dapat diterapkan apabila kedudukan para pihak seimbang. Apabila tidak seimbang, asas kebebasan berkontrak dapat diterapkan dengan catatan ada pengawasan dari Departemen Kehakiman.

b) Kedudukan hukum perjanjian tidak lagi selamanya $100 \%$ masuk dalam lapangan hukum privat. Hukum perjanjian selain berdimensi privat, dalam hal isinya menyangkut kepentingan hajat hidup orang banyak, juga berdimensi publik. Untuk melindungi kepentingan masyarakat konsumen dalam perjanjian baku, harus ada campur tangan Negara.

Klausula Eksonerasi Kehadiran klausula baku sudah banyak dapat kita temui dalam praktek perekonomian, namun yang perlu dikhawatrikan adalah dicantumkannya klausula eksonerasi pada perjanjian tersebut. Klausula Eksonerasi adalah klausul yang mengandung membatasi atau bahkan menghapus sama sekali tanggung jawab yang semestinya dibebankan kepada pihak produsen/penyalur produk (penjual). Tidak semua kontrak baku adalah klausula eksonerasi. Jika melihat pada Pasal 18 ayat (1) UndangUndang No. 8 Tahun 1999 tentang Perlindungan Konsumen, klausula baku dan klausula eksonerasi berbeda. Artinya klausula baku adalah klausula yang dibuat sepihak oleh pelaku usaha, tetapi isinya tidak boleh mengarah kepada klausula eksonerasi.

Klausula eksonerasi hanya dapat digunakan dalam pelaksanaan perjanjian dengan itikad baik. Eksonerasi yang timbul karena kesengajaan pengusaha/penyedia jasa dan menyebabkan kerugian bagi konsumen bertentangan dengan kesusilaan karenanya pengadilan dapat mengesampingkan klausula eksonorasi tersebut.

Bentuk bahwa tanggung jawab dari akibat hukum karena tidak atau kurang baik memenuhi kewajiban-kewajiban, dikurangi atau dihapuskan (misalnya ganti kerugian dalam hal ingkar janji); Bentuk bahwa kewajiban-kewajiban sendiri, yang biasanya dibebankan pada pihak untuk mana syarat dibuat, dibatasi atau dihapuskan (misalnya perluasan pengertian keadaan darurat); Bentuk bahwa kewajiban-kewajiban dicipta syarat-syarat pembebasan (vrijwarings bedingen); salah satu pihak dibebankan dengan kewajiban untuk memikul tanggung jawab pihak lain yang mungkin ada untuk kerugian yang diderita oleh pihak ketiga. syarat-syarat eksonerasi ini merupakan suatu ketentuan yang dibuat untuk menghindari adanya ketidakadilan yang menyebabkan kerugian bagi salah satu pihak dalam pelaksanaan perjanjian.

\section{Kesimpulan}

adanya pelaku usaha pada bisnis jasa perparkiran, baik milik pemerintah maupun milik swasta yang berusaha mengalihkan beban tanggung jawabnya kepada konsumen atas kehilangan atau kerusakan kendaraan atau barang berharga konsumen di lahan parkir yang dikelola olehnya. Tentu hal demikian bertentangan dengan Undang-Undang No. 8 Tahun 1999 tentang Perlindungan Konsumen 


\section{DAFTAR PUSTAKA}

Abdulhay, Marheinis. Hukum Perdata. Jakarta: Pembinaan UPN. 2006. Agustin, Risa. Kamus Lengkap Bahasa Indonesia. Surabaya: Serba Jaya. Ali, Zainuddin.Metode Penelitian Hukum. Jakarta: PT Sinar Grafika. 2011.

Badrulzaman, Mariam Darus.Pembentukan Hukum Nasional dan Permasalahnnya. Bandung: PT Alumni Bandung. 1980.

Bintang, Sanusi dan Dahlan. Pokok-Pokok Hukum Ekonomi dan Bisnis. Bandung: PT Citra Aditya Bakti. 2000.

Dj. A. Simarmata.Reformasi Ekonomi Menurut Undang-Undang Dasar 1945:Kajian Ringkas dan Intrepretasi Teoritis. Jakarta: Lembaga Penerbit Fakultas Ekonomi. 1998.

Fuady, Munir. Perbuatan Melawan Hukum. Bandung: PT Citra Aditya Bakti. 2002. . Hukum Kontrak “Dari Sudut Pandang Hukum Bisnis” . Bandung: PT

Citra Aditya Bakti. 2007. . Perbuatan Melawan Hukum Pendekatan Kontemporer” . Bandung: PT

Citra Aditya Bakti. 2010. Hamzah, Andi. Kamus Hukum. Jakarta: Ghalia Indonesia. 2005.

Hariri, Wawan Muhwan. Hukum Perikatan (Dilengkapi Hukum Perikatan dalam Islam). Bandung: CV Pustaka Setia. 2011.

Kristiyanti, Celina Tri Siwi.Hukum Perlindungan Konsumen. Jakarta: PT Sinar Grafika. 2009.

Marzuki, Peter Mahmud.Penelitian Hukum. Jakarta: Kencana. 2010. Miru, Ahmadi. Prinsip-Prinsip Perlindungan Hukum Bagi Konsumen di Indonesia. Jakarta: PT Raja Grafindo Persada. 2011. dan Sutarman Yodo.Hukum Perlindungan Kosumen. Jakarta: PT Raja Grafindo Persada. 2011.

Muhammad, Abdulkadir. Hukum dan Penelitian Hukum. Bandung: PT Citra Aditya Bakti. 2004.

Hukum Perusahaan Indonesia. Bandung: PT Citra Aditya Bakti. 2010.

Muljadi, Kartini dan Gunawan Widjaja.Perikatan Yang Lahir dari Perjanjian. Jakarta: PT Raja Grafindo Persada. 2003.

Nasution, Az. Hukum Perlindungan Konsumen Suatu Pengantar. Jakarta: Diadit Media. 2011.

Nieuwenhuis, J. H. Pokok-Pokok Hukum Perikatan.Terjemahan oleh Djasadin Saragih. Surabaya: Universitas Airlangga. Pramono, Nindyo. Hukum Komersil, Jakarta, Pusat Penerbitan UT, 2003. 
Rasyida,Andi Astari.Analisis Hukum Terhadap Klausula Baku Pada Kartu Studio Pass di Trans Studio Makassar. Fakultas Hukum Hasanuddin Makassar. 2015.

Sasongko, Wahyu.Dasar-Dasar Ilmu Hukum. Bandar Lampung: Universitas Lampung. 2013.

.Ketentuan-Ketentuan Pokok Hukum Perlindungan Konsumen. Bandar Lampung: Universitas Lampung. 2016. Shidarta.Hukum Perlindungan Konsumen. Jakarta: Grasindo. 2000.

Shofie, Yusuf.Perlindungan Konsumen dan Instrumen-Instrumen Hukumnya. Bandung: Citra Aditya Bakti. 2009.

Sidabalok, Janus.Hukum Perlindungan Konsumen di Indonesia. Bandung: Citra Aditya Bakti. 2010.

Subekti, Hukum Perjanjian. Jakarta: Intermasa. 2002. Sudaryatmo.Hukum \& Advokasi Konsumen. Bandung: PT Citra Aditya Bakti. 1999.

Syahmin.Hukum Kontrak Internasional. Jakarta: Rajawali Pers. 2005.

Syawali, Husni dan Neni Sri Imaniyati. 2000.Hukum Perlindungan Konsumen. Bandung: Madar Maju

Tobing, David M. L. Hukum Perlindungan Konsumen dan Parkir. Jakarta: Timpani. 2007.

Widjaja, Gunawan dan Ahmad Yani.Hukum Tentang Perlindungan Konsumen.Jakarta: PT Gramedia Pustaka Utama. 2003.

Basri. Perlindungan Hukum Terhadap Konsumen Parkir. Perspektif Vol. xx No. 1. 2015. Sari, Dwi Tyas Ratna. Analisis Yuridis Perjanjian Baku dalam Perjanjian Parkir yang Dibuat oleh PT. Securindo Packtama Indonesia di Surabaya. EJournal UNESA Vol 1 No. 1. 2013.

Sihombing, Anhar C. Kebebasan Berkontrak dan Perlindungan Tertanggung dalam Perjanjian Asuransi di Indonesia. Jurnal Hukum Bisnis, Vol 29 No. 2. 2010. Wahyuningdyah, Kingkin. Perlindungan Hukum Terhadap Konsumen Melalui Larangan Pencantuman Klausula Baku. Fiat Justicia Jurnal Ilmu Hukum Vol. 1. No. 2. 2007. 